\title{
Pedagogical Conditions for Ensuring the Quality of Engineering Training in Ukraine in the 19th Century
}

\author{
Viacheslav Oleksenko \\ National Technical University, "Kharkiv Polytechnic Institute," Ukraine
}

\begin{abstract}
This article discusses the research results of the didactic system of training engineers at the Kharkiv Practical Technological Institute (Ukraine). It establishes the historical context for the founding of the first technical institute on the Left-Bank of Ukraine, including accounting for the great need for civilian private enterprises in engineering personnel, as well as the influence of businessmen. In carrying out the institutional analysis of the basic organizational and normative documents that regulate the educational process, particular attention is paid to class schedules and curricula from the opening of the institute in 1885 to 1891 . The article comprehensively outlines the components of ensuring the quality of engineering training and considers the modernization of the process of training engineers. It also identifies and substantiates information parameters of the students, including the social status of future engineers by estate and faith. This research produces a holistic understanding of student training and expulsion. The research results are based on archival materials and literature of the 19th century.
\end{abstract}

Keywords: modernization, educational process, engineering training, quality, organizational and normative documents

ISSN 2560-8371

DOI: 10.24908/encounters.v21i0.14098 


\section{Conditions pédagogiques pour assurer la qualité de la formation en ingénieur en Ukraine au 19e siècle}

\section{Résumé}

Cet article présente les résultats de recherche du système didactique des ingénieurs de formation à l'Institut Technologique Pratique de Kharkiv (Ukraine). Il établit le contexte historique de la fondation du premier institut technique sur la rive gauche de l'Ukraine, notamment en tenant compte du grand besoin d'entreprises privées civiles en personnel d'ingénierie, ainsi que de l'influence des hommes d'affaires. Lors de l'analyse institutionnelle des documents organisationnels et normatifs de base qui régissent le processus éducatif, une attention particulière est portée aux horaires de classe et aux programmes depuis l'ouverture de l'institut en 1885 jusqu'à 1891 . L'article décrit en détail les composants permettant de garantir la qualité de formation en ingénierie et envisage la modernisation du processus de formation des ingénieurs. II identifie et justifie également les paramètres d'information des étudiants, y compris le statut social des futurs ingénieurs par classe et par foi. Cette recherche produit une compréhension holistique de la formation et de l'expulsion des étudiants. Les résultats de la recherche sont basés sur des documents d'archives et de la littérature du 19e siècle.

Mots-clés: modernisation, processus pédagogique, formation d’ingénieur, qualité, documents organisationnels et normatifs

\section{Condiciones pedagógicas para garantizar la calidad de la formación en ingeniería en la Ucrania del siglo XIX}

\section{Resumen}

Este artículo presenta los resultados de la investigación del sistema didáctico de formación de ingenieros en el Instituto Tecnológico Práctico de Kharkiv (Ucrania). Establece el contexto histórico para la fundación del primer instituto técnico en la margen izquierda de Ucrania, incluida la contabilidad de la gran necesidad de empresas privadas civiles en el personal de ingeniería, así como la influencia de los empresarios. Al realizar el análisis institucional de los documentos básicos organizativos y normativos que regulan el proceso educativo, se presta especial atención a los horarios de clases y los planes de estudio desde la apertura del instituto en 1885 hasta 1891. El artículo describe de manera integral los componentes para asegurar la calidad de la formación en ingeniería y contempla la modernización del proceso de formación de ingenieros. También identifica y justifica los parámetros de 
información de los estudiantes, incluido el estatus social de los futuros ingenieros por clase y por fe. Esta investigación produce una comprensión holística de la formación y la expulsión de los estudiantes. Los resultados de la investigación se basan en materiales de archivo y literatura del siglo XIX.

Palabras clave: modernización, proceso educativo, formación en ingeniería, calidad, documentos organizacionales y normativos

\section{Introduction}

As an unprecedented global event, COVID-19 has shocked people no less than Germany's use of chemical warfare in 1915. In response, the Russian Empire involved a large number of engineers, who in record short time created and began to produce both weapons for and protection against chemical attacks. Among the best were engineers trained at the Kharkiv Practical Technological Institute (KHPTI). Despite the fact that there was no special training of specialists in poisonous substances in the Russian Empire, the knowledge gained in technical institutes was enough to produce a new type of weapon. Among other reasons that will be explored in this article, the success of engineer training through technical institutes-indicated by the Russian Empire's wartime production-is an element of the historical context that highlights the importance of this pedagogical exploration.

Technical higher education institutions on the territory of Ukraine first appeared in the 19th century. During this period, Ukrainian lands belonged to two states: the Russian Empire and the Austrian Empire. They were quite different not only in culture and living conditions, but also in educational institutions. Austria owned Western Ukraine, and all other Ukrainian lands came under the rule of the Russian Emperor and accounted for about $80 \%$ of the ethnic territory. Western Ukraine was divided and joined in parts to various administrative units of the Austrian Empire (since 1867, the Austro-Hungarian Empire). Galicia, Transcarpathia and Bukovyna had previously been under the rule of the Habsburgs, but now Transcarpathia had now became part of Hungary. Transcarpathia did not form a separate administrative unit. Galicia with its center in Lviv and Bukovyna with its center in Chernivtsi remained under Vienna's jurisdiction. Legislation and national policy in both parts of the Empire were different.

The takeover of Ukrainian lands by the Russian Empire was accompanied by the introduction of a unified system of government through the introduction of a general imperial administrative system. As a result, nine provinces were formed. Kharkiv, Chernihiv and Poltava provinces were located on the left bank of the Dnieper River. Kyiv, Volyn and Podil provinces were located on the right bank of the Dnieper River. Katerinoslav, Kherson and Tavriya (with the whole Crimea) provinces were located in 
the southern part of Ukraine. All administrative executive power in the provinces was exercised by governors appointed by the Emperor.

The basics of technical knowledge were first given in gymnasiums in the 19th century. Further training was provided at universities, where scientific research was carried out in technical fields. The first technical higher education institution in Ukraine was established in Lviv (Western Ukraine). The Imperial-Royal Technical Academy opened in 1844 with technical and trade departments. Currently known as Lviv Polytechnic National University (LPNU), it was formed gradually. Firstly, the ImperialRoyal Real School was opened in 1816. It had three classes. The educational process was carried out on the basis of German educational programs, which were adapted to local conditions and requirements. After ten years, the school was reorganized into a college (the Imperial-Royal College of Technical Sciences and Trade). The college was then transformed into an academy in 1835 (the Imperial-Royal Real Trade Academy). The technical department was opened at this academy in 1841 (for a further history of the LPNU, see Bobalo, 2008; Bobalo, 2010; Central State Historical Archive of Ukraine, Lviv, $f$ 146).

The technical development of Western Ukraine was low and slow in the second half of the 19th century. Engines and other machines were concentrated mainly in factories in the central and western regions of the Austro-Hungarian Empire, whereas $95 \%$ of factories in Western Ukraine remained small (employed up to five people). Their technical equipment was relatively primitive. Technical modernization and growth in the number of medium and large factories lasted until the end of the 19th century. Raw materials were mainly exported from Western Ukraine, and finished goods were produced abroad and returned for sale. Significant remnants of feudal relations in the pricing policy of cheap raw materials and expensive finished goods led to difficult economic living conditions. The peasants were forced to seek a better fate in other places and countries. In the 1990 s, more than 250,000 people immigrated to Canada, the United States, Australia and other countries.

In the rest of Ukraine, the share of foreign capital in industry increased in the second half of the 19th century. Plants, factories, mines and railways were actively built. Production processes were mechanized in all industries by introducing steam engines. The metallurgical, coalmining, and ore mining industries underwent intense development, and significant progress was made in agriculture and transport engineering. The Kharkiv province stood out, where even steam locomotives were manufactured. However, the heads of domestic factories predominantly did not have any higher education, and many were citizens from other states. The staffing problem hampered the industrial development. The entire Empire, and especially Ukraine, felt a great need for technologists and other engineering specialists. Socio-economic development was accompanied by the progress in technology, but technological advancement was impossible without appropriate specialists in plants and factories. Moreover, there was a need to develop productive theory of steam engines and other 
promising engineering ideas. It was necessary to give a scientific solution to practical problems, and this could only be provided by engineering education. However, the existing educational institutes could not satisfy the needs for specialist training in the significantly increased territory of the Russian Empire.

Western Ukraine was a market for goods produced in the central provinces of the Empire and was an affordable source of minerals and agricultural products, but the industry of this region developed less intensively and the problem of shortage of business leaders was less acute. Furthermore, the territory of Western Ukraine was many times smaller. Because of the limitations of other institutes like the St. Petersburg Practical Technological Institute and the historical context of technological and industrial development of Western Ukraine, along with the extensive pre-existing literature on the LPNU, the focus of this study is instead on engineering training in the $\mathrm{KHPTI}$. The article will provide an in-depth examination of KHPTI, the second higher technical education institution of Ukraine, or as it is currently known, the National Technical University "Kharkiv Polytechnic Institute" (NTUKHPI).

\section{Literature Review}

The recent studies and publications devoted to the study of the history of the KHPTI focus on individuals, facts, discoveries, and departments. Such papers do not provide the historical context and developments that led to the program at the KHPTI, nor do they reveal the process of training engineers in an educational institution.

Atroshchenko (1985) was the first successful attempt at a comprehensive and indepth presentation of the history of the KHPTI for first 100 years of its existence. The paper examined the main stages of the development of the institute and showed its contribution to the training of engineering and scientific personnel and the development of domestic science and technology. However, because of the little attention paid to the important period of the opening and formation of the KHPTI in the 19th century, one can make an erroneous conclusion that the organization of the institute began in 1870. Nothing was noted about the problems of construction of the KHPTI. Although it indicated that the institute's plan was to build seven buildings, by 1885 , only five were built: the main, physical and chemical buildings, a residential building, and a mechanical workshop. It discussed where the engineers were trained but did not detail how.

Kostenko (1999a) described the main events and facts that tell the history of the formation and development of the KHPTI from 1885 to 1998. The material from the 19th century was copied to the NTUKHPI site from this book. It helps provide important history to contribute to a better understanding of the era in which the institution was formed and developed and traces the connection between generations. The work benefited from the inclusion of extensive compilation material, including 
instructions for the KHPTI inspection, a description of the uniform of the KHPTI students, saluting rules, a report on the state of the KHPTI for 1903, and rules on penalties imposed on students. The book outlined the two committees of the institute: the Economic Committee resolved issues of construction, and the provision of laboratories and offices, among other things; and, the Study Committee dealt with issues of educational, scientific and social work. Significant attention was also paid to the teaching staff, including academicians N. Beketov, P. Budnikov, A. Valter, L. Landau, A. Liapunov and others worked at the KHPTI, and who contributed to the prestige of national science. Kostenko (1999a) focused on the fact that outstanding people trained future engineers, and with such teachers, students became good specialists. Similarly, Lisatchuk's (2003) work provided brief historical information about the formation and development of the KHPTI since 1885 to 2003 through valuable photographic materials.

Tovazhnyansky (2000) revealed how the education received at the institute allowed many to become famous scientists, designers, talented production organizers, and experienced leaders of industrial enterprises and research institutes. However, the book contained few specific ideas about the pedagogical process in the 19th century. While the above material may be useful for contemporary students to increase their confidence in the merits of the work of an engineer, but they are not as useful in providing the necessary historical context for thorough pedagogical analysis.

Despite the abundance of published material, the existing literature does not include a complete description of the process of training engineers at the KHPTI in the 19th century. Until now, the curricula and class schedule of this historical period remained unexplored. Additionally, "[a]ccording to the data for 1885, even among the heads of industrial enterprises, out of 22322 people, only 1608 people had higher and secondary technical education" (Atroshchenko, 1985, p. 12). The country needed engineers, but there were only 125 people enrolled in the first course of the KHPTI in 1885. According to documentation, this is the number of applicants indicated. But of the 125 in the first class, only 38 students completed their education. No work has investigated this discrepancy until now.

In order to address this gap in current literature, this article describes the results of research on the pedagogical process of engineering training at the KHPTI from 1885 to 1891 , and analyses the main organizational and normative documents that regulate the educational process to answer the two central research questions: why were there only 125 people enrolled in the first 1885 course at the KHPTI? and, why did only 38 of those students complete their education at the KHPTI? 


\section{Results}

Aimed at establishing the historical development and context, this article is focused on the study and theoretical reproduction of the history of the educational process at the KHPTI in the fullness of interrelationships in the educational process and in many specific manifestations. The historical approach to this research utilized abstract historical, historical and archival research methods. ${ }^{1}$

Firstly, I will discuss some of the little-known features of the KHPTI organization and their historical aspects. This will help explain why the KHPTI received support from local authorities and the Cabinet of Ministers willingly meet the numerous needs of the new institution since 1885. It will also become clear why the KHPTI did not cease to exist at the end of 1887 but was only temporarily closed.

Russia's defeat in the Crimean War (1853-1856) exposed its great economic and technical backwardness. With the signing of the surrender came the loss of religious influence over vast territories and the deprivation of the Empire of the right to have a navy in the Black Sea along with coastal fortresses and arsenals. This in turn forced the government of Alexander II to carry out a series of reforms. Not only did the reforms abolish serfdom, but they also slightly increased the number of education institutions and improved the organization of their pedagogical processes and revised curricula. The St. Petersburg Practical Technological Institute (SPPTI) received the status of a higher education institution (Bogdanovich, 1877; Smoliy, 2008, vol. 5; St. Petersburg State Technological Institute, 1998).

In such historical conditions, the question of the organization of the second higher technological educational institution was raised in the Russian government. It was originally proposed to open in Mykolayiv, Kherson province. The SPPTI was entrusted to develop a project of regulations for the new institute. The creation of the project was successful, but was also subject to strong and successful lobbying to prevent such a construction. At the same time, various reasons were put forward by those opposed to the project, including the absence of a university in Mykolayiv and the underdeveloped industry of the city (Kostenko, 1999a; Tovazhnyansky, 2000).

Gradually, the situation changed in the country, and the number of private companies increased. Private capital began to declare the need to train specialists for their companies and challenged the state monopoly on specialist training. The military orientation of Russia meant that even metallurgy and mining developed according to the demands and requirements of the military industry. After graduating from the SPPTI, certified specialists were automatically recruited for military or public service, meaning that there was still a shortage of specialists for private companies. Sugar and textile companies that did not work directly for the army also faced engineer shortages.

At the end of the 1860s the question about the opening of a technical institute arose once again. This time it was very acute and unambiguous without opposition daring to object in the face of an order from the Minister of Finance for positive 
resolution. In October 1870, the SPPTI training committee took the order quite seriously. Kharkiv, Odessa, and Kazan-all of which had developed industries-were considered. These cities already had universities that could provide assistance to the new institute with both teachers and textbooks. In the end, preference was given to Kharkiv, as a city located near coal deposits and had sugar plants (Central State Historical Archive of St. Petersburg, f. 733, reg. 159, No. 62, p. 6-12; Onoprienko \& Shcherban, 1990). Sugar production in Kharkiv province was approximately $15 \%$ of what the whole Russian Empire produced. At the same time, Ukraine produced approximately $90 \%$ of the Empire's sugar (Turchenko \& Moroko, 2011; Vobliy, 1930, p. $277,278)^{2}$

Construction of the new institute began in the 1870s. The authorities of the city founded the Kharkiv Real School in order to provide the institute with applicants. In 1871, eight SPPTI graduates were sent abroad to prepare for teaching activities in the future KHPTI (Atroshchenko, 1985; Kostenko, 1999a; Proceedings, 1905). Construction ceased in the early 1880s. All buildings from the Ministry of Finance were transferred to the Ministry of Public Education. Both ministries slowed down the organization of the KHPTI. Various disputes arose over the opening of the institute, including whether it was possible for the college and the transfer of the existing buildings to the local university (Kirpychov, 1895).

It seems that businessmen ultimately helped end the controversy and organize the KHPTI. The sharp change in the opinion of the Ministers of Finance and Public Education in relation to the KHPTI coincided with the visit of delegates of the Congress of Mining Industrialists of the South of Russia to the Minister of Public Education and the Minister of Internal Affairs. The trip occurred with the aim of opening the KHPTI (Dietmar, 1908). Miners owned huge capital, dozens of sea vessels, hundreds of steam locomotives, and thousands of railway cars filled with coal and iron ore. The less than coincidental alignment signals that mining organization influenced both the economy and the politics of Russia. Soon after the said visit, the two ministers organized the adoption of a number of documents that regulated the life of the KHPTI and allowed its opening, as well as the allocation of a sufficient amount of funds. Moreover, the money was allocated both for the completion of construction and for the maintenance of the institute for five years.

Permission to open the KHPTI was signed on April 16, 1885. During this time, some buildings became inappropriate for studying. The first director of the institute, Professor V. Kirpychov, quickly organized the repair of premises, laboratory equipment, and construction of new buildings, as well as specialist training (Kirpychov, 1895).

Next, I will briefly describe the educational process at the KHPTI on the basis of constituent documents. Those who studied at the KHPTI will be called students as it is common today though they were called pupils in the 19th century. 
Initially, the institute had mechanical and chemical departments which trained mechanical engineers of steam engines, hydraulic engines, and technologists in the production and processing of minerals, protein and fibrous substances, fats, and in other specialties. The first enrollment of students was in August 1885. Applications were submitted by 286 people, of which 209 were examined, and 138 passed exams. Of the 138 successful at exams, 125 students were admitted: 85 to the mechanical department and 40 to the chemical department. As there were more than enough people willing to join the KHPTI, competitive exams in mathematics, physics and Russian were opened for candidates entering the institute within the gymnasium course (Kostenko, 1999a; Oleksenko, 2006).

My research has shown that the KHPTI could not enroll all 138 people who passed the entrance exams in 1885. The KHPTI Charter prohibited more than 125 enrolled students in the first year. According to the Charter, studying at the KHPTI lasted five years and consisted of five one-year courses. Studying began on September 1 and ended on April 30 (Oleksenko, 2006; Proceedings, 1905). A one-year term was provided only for the study of theoretical disciplines. A necessary component of the educational process was the practical education of students in factories and plants, which qualitatively distinguished professional training at the KHPTI from training in universities. Practical training took place separately for mechanical and chemical departments. The KHPTI management and especially V. Kirpychov encouraged students' excursions to sugar, cement, shipbuilding, and other plants in Ukraine, as well as summer and autumn internships on the country's railways (Kharkiv Region State Archive, Nos. 102, 110, 126, 127, 134, 147, 148).

In May, exams were held at each course. Exam results only partially influenced further study. Students were either expelled from the institute or transferred to the next course based on the results of the academic year and exams. The average annual grade for each subject was based on the grades obtained by the student in the rehearsals and in the annual exam (see formula 1). I derived this formula based on the information contained in archival documents and from Proceedings (1905). The rehearsals were in fact weekly exams, and all grades from the rehearsals should be satisfactory or higher.

$$
R=\frac{\sum_{i=1}^{k} r_{i}+k R_{e}}{2 k},
$$

Where $\mathrm{R}$ is a student's annual grade, $r_{i}$ is a grade for the $i$-th compulsory rehearsal, $R_{e}$ is an examination grade, and $k$ is a number of compulsory rehearsals for the academic year. 
It was mandatory for students to rehearse on time. The deadline for the rehearsals missed due to illness or other very serious circumstances was set by the director assistant. The missed rehearsal was awarded a grade of zero. Not all students were admitted to the exams, rather only those students who properly performed during their year's studies, performed satisfactorily on all established graphic, laboratory and other practical work, and did not have unsatisfactory grades on rehearsals during the year in any subject. In some cases, the Study Committee could admit to the exam those students who had an unsatisfactory grade in just one of the rehearsal subjects. If the student was admitted to the exam with an unsatisfactory grade in the rehearsals, and he passed this exam, he was given a grade of three. Those students who satisfactorily passed all the exams, with a grade of not less than three for any subject, were transferred to the next course. According to the decision of the Study Committee, a student who did not pass one of the transitional exams was allowed to pass the exam again after the holidays to transfer to the next course. Second years on the same repeated course were only possible for special reasons and circumstances and could only occur for students twice during their study at the institute. Students were unable to spend a third year on the same course. The degree of success of students in each of the compulsory subjects was assessed on a six-grade scale: from zero to five, where zero meant no knowledge, and five meant very good or excellent (Proceedings, 1905). Weekly control and mandatory expulsion from the institute in case of poor performance meant that students studied hard during the year. Students were aware of their responsibility for the consequences of their studies. The current control was carried out through rehearsals, which were included in the training schedule.

Class schedule is one of the main organizational documents governing the educational process. As a result of the analysis of archival materials related to the schedule of educational classes, my research was able to conclude the follow details about the education process: each lecture lasted about 60 minutes, studies began at 9 am, and the maximum course load was seven hours. For example, in 1885, study usually lasted from 9 am to $3 \mathrm{pm}$ (on Monday from 9 am to $2 \mathrm{pm}$ and on Friday from 10 am to $3 \mathrm{pm}$ ). Students studied from Monday to Saturday, with the class schedule lasting for the whole year. In the first year, students from both departments studied together on the same schedule.

As a rule, there was a gradual load of complex subjects during the day. In the morning subjects were more difficult, and then less difficult ones were scheduled for later in the day. For example, in the first year of 1885, on Wednesday, two hours of lectures on differential and integral calculus were given first. Then there were two hours of foreign languages study and two hours of drawing. There were, however, exceptions in some years. For example, in 1891, Monday was particularly difficult for first-year students. The schedule included differential and integral calculus from 9 am to $11 \mathrm{am}$, followed by one hour of chemistry. Then there was an hour for each subject of mechanics, physics, and descriptive geometry. Typically, during the week, a uniform 
load of subjects on the complexity. Students studied three foreign languages: English, French, German. The class schedule was made without breaks, and classes could be doubled. For example, students in the second year of 1891 on Tuesdays from 9 am to $10 \mathrm{am}$ and from $10 \mathrm{am}$ to $11 \mathrm{am}$, attended lectures on geodesy. Drawing and painting were the last classes on the schedule in each year, although it is already dark in Kharkiv in winter after $2 \mathrm{pm}$. A well-known feature of these subjects is the need for thoughtful lighting of the training place. The auditorium fund was used effectively. Heating of auditoriums in the winter was also taken into account.

I found that an inspectorate was set up at the institute in order to monitor and inform the Director about the lectures that did not take place, as well as about their untimely beginning or end. The Director headed the Study Committee. This committee considered the candidacy of new teachers, the preparation of curricula, load distribution, and other pragmatic and bureaucratic functions of the institute (Proceedings, 1905; Kharkiv Region State Archive).

The results of the analysis of archival materials regarding the amount of study load are presented in the form of Table 1.

Table 1

The study load in the first year

\begin{tabular}{|l|l|l|}
\hline Educational subjects & $1885 / 1886$ (hours) & $1890 / 1891$ (hours) \\
\hline The law of God & 2 & 2 \\
\hline Analytical geometry & 2 & 2 \\
\hline Differential and integral calculus & 3 & 4 \\
\hline Physics & 3 & 3 \\
\hline Chemistry & 0 & 3 \\
\hline Mechanics & 3 & 3 \\
\hline Descriptive geometry & 3 & 3 \\
\hline Drawing & 6 & 6 \\
\hline Painting & 4 & 4 \\
\hline Languages & 4 & 3 \\
\hline
\end{tabular}

Through this analysis, I found that curriculum was progressive, rather than conservative and unchanging. In the first year they started teaching chemistry for three hours per week. The teaching of higher mathematics was increased by one hour and the study of foreign languages was reduced by one hour since 1887 . The reasons for 
allocating hours for chemistry are clear. There was a chemical department at the $\mathrm{KHPTI}$ and the industry required the chemical knowledge. But the increase in hours for the study of mathematics requires more detailed justification.

The Director of the KHPTI, V. Kirpychov, repeatedly proved the importance of mastering future engineers in mathematics, chemistry, physics, and mechanics. He considered them the foundation of all knowledge for engineers. The world-famous professor gave mathematics the leading place among all disciplines because he saw it as the basis of all sciences. His opinion was shared by the KHPTI team. They believed that technical activity would progress only if the leading role in the creative process belonged to mathematics, which was called the true language of modern science (Chekanov, 1982, pp. 122-127; Kharkiv Region State Archive, No. 558; Kostenko, 1999b; Kirpychov, 1890).

The analysis of subject programs of the KHPTI showed that the meaning of the term "program" has changed significantly. Unlike the modern study programs, the KHPTI programs did not clearly define the place of each discipline in the training system of future technologists. There is no documentation of the disclosure of ultimate and specific learning objectives that form the hierarchical system of learning content. The main forms of training organization and control methods were not specified, as only the content of each subject was captured. At the same time, it should be noted that the subjects were taught at a high level, taking into account the modern achievements of science at that time (Kharkiv Region State Archive; Proceedings, 1906).

The library had an especially important role in the training of engineers at the KHPTI. It helped students prepare for rehearsals and exams, complete their theses, and perform other scholastic functions. By 1895, it numbered over 8000 volumes of various books and magazines related to the subjects taught. Up to 100 scientific and technical journals were subscribed annually, mainly in foreign languages. Even alreadygraduated engineers repeatedly applied to the KHPTI to allow them to use the resources in the library in order to solve engineering problems (Kirpychov, 1895).

Students who had completed a full academic curriculum at the KHPTI, passed "final tests," which were a prototype of modern state exams. Successful completion of the exams was necessary for students to become technologists or engineertechnologists. Final tests for students were conducted at special examination commissions at the mechanical and chemical departments. Each commission consisted of a chairman and three members. The chairman and members of the commission were appointed annually by the Ministry of National Education. Each commission was given the right to invite teachers of the institute to help. Students who passed a full academic curriculum at the institute and had average grades in each group of special subjects and a general average grade in auxiliary subjects not less than three were admitted to the commissions. The commission awarded those who passed the test with the engineer-technologist degree or the technologist degree. The 
engineer-technologist degree could be awarded only to those students who had completed an academic curriculum at the institute with average grades in each group of special subjects and a grade for each project of at least four, as well as a total average grade of auxiliary subjects of at least three and a half (Proceedings, 1905).

Special subjects with their division into groups and auxiliary subjects that made up one group were approved by the Minister of National Education. For students in the mechanical department, the first group, called "Mathematics and Physics" included: analytical geometry, differential calculus, integral calculus, elementary mechanics, analytical mechanics, physics, and chemistry. For this department, descriptive geometry fell into the group of auxiliary subjects. For students of the chemistry department, none of the mathematical disciplines fell into the groups of special subjects. The group of auxiliary subjects included descriptive geometry and mathematics, which combined analytical geometry with differential and integral calculus (Proceedings, 1905).

The first graduation of engineers took place in the KHPTI in 1890. No existing literature has investigated why 125 people entered, and only 38 received higher technical education, nor has it accounted for the remaining 87 students who did not complete their education. Originally, I had put forward the null hypothesis: "All students were expelled due to poor performance." It turned out to be more difficult to test the hypothesis than it initially seemed. In order to address this, a detailed study of the archival materials was necessary. The new data raised several new questions. Based on archival materials, I obtained a list of the KHPTI students and their academic scores (Kharkiv Region State Archive, Nos. 43, 44, 58, 62, 69, 86, 92, 113, 116, 117, 122, 124, $139,144)$. As a result, the null hypothesis was not confirmed. Indeed, many students were expelled due to poor performance. Not everyone withstood the high demands and strict discipline.

On January 1, 1887 there were two courses at the KHPTI. Moreover, 121 students studied in the first year, and only 83 in the second year. Of the second-year students, 82 were admitted to the May exams, 69 of those students passed the exams, and 11 were left for a second course. This led me to conclude that three students were expelled, which is considerably less than the 42 that were originally unaccounted for in the numbers. By January 1, 1888 there were no longer 69 students in the third year, rather than 45 . There were no exams during this time. Moreover, three students entered the third year and two students entered the second year of the KHPTI in August and September 1887 (Kharkiv Region State Archive, No. 68, p. 6). Thus, 27 students were expelled in the period August to December 1887. Given the historical situation in the country at that time, it is reasonable to assume that the deductions took place in December 1887 due to disobedience against state authorities. Many students were arrested and sent to prison during that time. The government cracked down on students for trying to assassinate the king. A total of 106 people were expelled from the KHPTI in 1887, including one who died. The vast majority of students was expelled 
for violations of discipline and "misdemeanors committed by them" (Kharkiv Region State Archive, No. 68, p. 6). By January 1, 1890, 38 of the 45 students who remained, received engineer-technologist degrees and technologist degrees (Kharkiv Region State Archive, Nos. 17, 61, 68, 85, 103, 110, 134, 146).

In 1886, the KHPTI carried out a second admission of students. Quantitatively, it was not as high as the previous cycle of admissions or the one that would follow it. In 1887, only 122 first-year students entered. In May 1887, 114 of 121 students were admitted to the exams. Of the 114 students, 86 of them passed the exams and four remained for the second course. The rest were expelled. Due to disobedience to the authorities and revolutionary activity and violation of the Statute of the Institute, on January 1, 1888, 78 students were enrolled in the second-year course. On January 1 , 1890,77 people were enrolled in the fourth-year course. During the year, enrollment numbers decreased by another nine people. Thus, before the final exams, there were 68 students on the fifth-year list. In the mechanical department, 20 of 29 students received the engineer-technologist degree, and eight people received the technologist degree. N. Kartashov received the engineer-technologist degree with an inscription on a marble plaque. One student was left to study for another year. In the chemical department, 24 students of 39 students received the engineer-technologist degree, and 12 students received the technologist degree. Yu. Nankin received the engineertechnologist degree, also with an inscription on a marble plaque. One student died, and another student fell ill. One student was dismissed from the institute with the right of re-admission in January 1892 (Kharkiv Region State Archive, No. 68, p. 6; No. 134, pp. 21-23; No. 146, pp. 22-31).

The analysis of the schedule of final exams shows that the exams were held in each department separately and on different days and months. The mechanical department held exams in May, while the chemical department held theirs in June 1891. To do this, students were divided into groups. For example, on June 3, 1891, 22 students of the chemical department took the exams. All 22 successfully passed their exams, with 14 who received the engineer-technologist degree and eight who received the technologist degree. The next day, ten students received the engineer-technologist degree and four received the technologist degree. In 1891, 64 people received the higher technical education, which is almost twice as much as the previous year. Note that only men studied at the KHPTI in 19th century.

The analysis of the KHPTI student distribution according to their faith for the entire research period, 1885-1891, showed that the vast majority were Orthodox (70-78\%), followed by Roman Catholics (7.5-13\%) and Jews (9.5-10\%). Protestants and Armenian-Gregorians were equal in numbers (2-3\%), and approximately less than one per cent $(0.5-0.75 \%)$ of students were other religions (Kharkiv Region State Archive).

The analysis of the student distribution according to their estate shows a strong preference for the children of nobles and officials (39-42\%). Approximately the same number of children of burghers, merchants of the second guild and artisans were 
enrolled. Approximately $2-4 \%$ of students were the children of clergy, peasants, Cossacks, honorary citizens and merchants of the first guild. Separately, there has been a notable increase in the number of foreigners to 3-3.5\% since 1888 (Kharkiv Region State Archive).

\section{Conclusion}

From archival materials, I have concluded that the integral components of ensuring the quality of engineering training in the KHPTI from 1885 to 1891 were based on a number of aspects. Firstly, the implementation of information support for the content of the educational process on the basis of curricula, study programs, and class schedules. Secondly, the establishment of lecture as the only form of organization of the educational process. Thirdly, the implementation of current and final control. The final control took place at the exams in May. Students' knowledge was assessed on a sixgrade scale according to the mathematical formula developed in the above analysis. Fourthly, the introduction of obligatory rehearsals into the educational process, but not into all subjects. Fifthly, the observance of military discipline, and awareness of students' responsibility for the consequences of their actions. Sixthly, the teaching of subjects by well-known scientists and experienced lecturers. Lastly, the conduction of practical training in factories and plants as a necessary part of the pedagogical process.

The philosophical condition for ensuring the quality of engineering training at the KHPTI was the introduction of educational technologies created on the basis of the responsibility of all the members of the educational process, taking into account the basic organizational and regulatory documents.

Based on the analysis of the constituent, organizational, regulatory and archival documents, this work has come to a number of conclusions. The schedule of classes provided the optimal mode of students' duties during the academic year. Disciplines were evenly distributed both during the day and during the week with the effective use of classrooms. The curriculum changed progressively, with new disciplines introduced for study and the numbers of hours were reasonably adjusted. Study programs were compiled in the correct hierarchy of academic subjects. In that period, the concept of "program" was considered more narrowly than today, but the content of the programs took into account the latest achievements of science at that time, resulting in the disciplines being taught at a high level.

Based on the regularity of unity of historical and modern methods of the scientific research, this work first identified and substantiated the information parameters of the student body during 1885-1891 at the KHPTI. I found the reasons for the two to three times reduction in the number of students from the moment of admission to the number of students who actually received an engineering degree. It has been 
established that unsatisfactory grades in exams are far from the main reason for the incompletion of programs. Many students were not allowed to take the exams. Too many students were expelled for violating the discipline and the Institute's Charter, or for misdemeanors. The additional analysis of the social status of students has allowed conclusions that there was preference for the children of officials and nobles to study at the KHPTI and the vast majority of students were Orthodox.

\section{Implications}

The Study Committee periodically carried out the modernization of the process of engineering training at the KHPTI. For example, rehearsals were replaced by practical exercises and partly half-year control was introduced in 1898. Corresponding changes were made to the curriculum and class schedule. In 1905, a subject training system was introduced at the KHPTI. It differed from the previous one in having greater flexibility. Monthly exams were allowed as students were ready throughout the academic year. Students had the right to take exams any number of times, and the term of training was not limited to a period.

With the advent of Soviet power, the institute was reorganized, and the system of engineering training generally accepted in the Soviet Union was introduced. It was a well-known lecture-practical system, which began to be called 'traditional' in independent Ukraine.

Socio-economic transformations in Ukraine, world processes of informatization and globalization, the adoption in the 21st century of a number of laws on education, which gave autonomy to higher educational institutions, created conditions for further educational modernization. In the NTUKHPI, the creation and development of a number of innovations took place through approbation in the form of successful pedagogical experiments. The most famous innovations have entered the stage of stable functioning. These are studies related to the formation of leadership and creative qualities in future engineers, as well as their readiness for professional and managerial activities; the formation of a mathematical culture among future specialists in engineer professions; and, the creation and implementation of innovative technologies in the training of future engineers.

In the conditions of the growth of information, the rapid aging of technical knowledge, and the need to intensify the learning process, it is effective to conduct educational classes with the provision of reflection regarding the social context of professional activity. Such classes are not only focused on professional interest, they also stand out for progredient active creative individual acquiring competencies by students in coherence with self-reflection, self-improvement, and self-realization, under the influence of collegiality. This research has shown that class efficiency is achieved 
when the educational, cognitive and creative activity of future engineers exceeds $75 \%$ of the academic time (Oleksenko, 2016; Oleksenko, 2017).

This system of pedagogical influences would maximize the quality of students' knowledge and minimize student expulsion. The technology of conducting such classes is difficult for practical implementation and belongs to high pedagogical technologies. ${ }^{3}$ Its improvement is the prospect of our scientific research.

\section{Notes}

1. This work used original materials related to the KHPTI. These are mostly documents of the Kharkiv Region State Archive. Documents from the period under study were collected in one fund number 770 and divided into a large number of cases. Cases are duly completed and signed by the responsible employees.

2. The region was famous not only by sugar production, as Kharkiv was an important businessand industrial center of the whole Ukraine, and a large railway junction. The powerful economic potential has been stated by other authors, including the number of factories and plants (Atroshchenko, 1985; Onoprienko \& Shcherban, 1990).

3. The concept of high educational technologies was substantiated and introduced in (Andrushchenko \& Oleksenko 2007).

\section{References}

Andrushchenko, V. \& Oleksenko V. (2007). High Educational Technologies. Higher Education in Ukraine, 2, 70-76.

Atroshchenko, V. (Ed.). (1985). Kharkiv Polytechnic Institute. 1885-1985: History of development. Kharkiv: Publishing Association "Higher School".

Bobalo, Yu. (Ed.). (2008). National University "Lviv Polytechnic.” Kyiv: Logos Ukraine. Bobalo, Yu. (Ed.). (2010). Lviv Polytechnic: Litteris et artibus. Kyiv-Lviv: Logos Ukraine. Bogdanovich, M. (1877). The Eastern War of 1853-1856. St. Petersburg: M. Stasiulevich.

Central State Historical Archive of St. Petersburg, f. 733.

Central State Historical Archive of Ukraine, Lviv, f. 146.

Chekanov, A. (1982). Victor Lvovich Kirpychov. Moscow: Nauka.

Dietmar, N. (Ed.). (1908). A brief outline of the history of the Congress of Mining Industrialists of the South of Russia. Kharkiv: Zilberberg.

Kharkiv Region State Archive, f. 770, reg. 1.

Kirpychov, V. (1890). The tasks of higher technical education. Kharkiv: V. Birukov.

Kirpychov, V. (1895). Kharkiv Practical Technological Institute decade 1885-1895.

Kharkiv: Zilberberg.

Kostenko, Yu. (Ed.). (1999a). Kharkiv Polytechnic: Events and facts. Kharkiv: Prapor. 
Kostenko, Yu. (Ed.). (1999b). Kharkiv Polytechnic: Scientists and teachers. Kharkiv: Prapor.

Lisatchuk, G. (Ed.). (2003). National Technical University "Kharkiv Polytechnic Institute." Kharkiv: NTU "KHPI".

Oleksenko, V. (2006). History of training specialists at the Kharkiv Technological Institute. Research on the history of technology, 8(1), 3-12.

Oleksenko, V. (2016). Technology of mastering educational material in universities. World Scientific News, 42(1), 119-131.

Oleksenko, V. (2017). Features of knowledge quality of university students in Ukraine. International Letters of Social and Humanistic Sciences, 76(1), 36-42, doi:10.18052/ www.scipress.com/ILSHS.76.36.

Onoprienko, V. \& Shcherban T. (1990). Formation of higher technical education in Ukraine. Kyiv: Naukova Dumka Publishing House.

Proceedings of the Kharkiv Technological Institute of Emperor Alexander III (1905). Kharkiv: Zilberberg.

Proceedings of the Kharkiv Technological Institute of Emperor Alexander III. (1906). Kharkiv: Zilberberg.

Smoliy, V. (Ed.). (2008). Encyclopedia of the history of Ukraine. Kyiv: Naukova Dumka Publishing House.

St. Petersburg State Technological Institute. 1828-1998. (1998). St. Petersburg: Lenizdat.

Tovazhnyansky, L. (Ed.). (2000). Kharkiv Polytechnic: At the turn of the millennium. Kharkiv: Prapor.

Turchenko, F. \& Moroko, V. (2011). History of Ukraine. Kyiv: Geneza.

Vobliy, K. (1930). Essays on the history of the Russian-Ukrainian sugar and beet industry. Kyiv: AUAN. 